\title{
THE PHENOMENON OF POPULISM IN TODAY'S UKRAINIAN POLITICAL SPACE
}

\author{
Yaroslav Farion ${ }^{1}$, Ihor Jazyschyn ${ }^{2}$ \\ Lviv Polytechnic National University, Lviv, Ukraine \\ ${ }^{1}$ Student of master program «Sociology», of Department of Sociology and Social Work \\ ${ }^{2}$ Senior lecturer (S.L.), of Department of Sociology and Social Work
}

Background: Populism, as a scientific issue and a phenomenon, is at the forefront of contemporary political and sociological research, which is related and has an important role, first of all, in the political processes taking place today in Ukraine and in the world during election campaigns.

Purpose: to learn, to investigate about the emergence and spread of populism in Ukraine and in the world.

Methods: Theoretical research methods were used to find out what kind of phenomen populism is, how populism manifests itself, who shapes it; Comparative analysis also were used to know the way see the problem of populism western and ukrainian scientists.

Results: Ukrainian researchers say that before the March 2019 presidential elections in Ukraine, the country's main ideology is increasingly aggravated by populism. It has been repeatedly emphasized that populism becomes a kind of "slow-motion", "populist traps" are set around, and politicians declare not their own views or even their own plans, but what is best perceived by the voter that they like to hear (Bila, 2019, April).

Conclusion: So, first of all, populism is an ideological and speculative orientation of politicians on the political expectations and desires of the general public, they use people's dissatisfaction with their lives. Second, as noted earlier, populism is used by politicians as an effective technology to gain and retain power.

Keywords: populism, politic, people, presidential elections, ideology, "slow-motion", "populist traps", politicians.

Популізм, як наукова проблематика, феномен, посідає чільне місце серед сучасних політичних та соціологічних досліджень, що пов'язано з його важливою роллю насамперед у політичних процесах, що відбуваються сьогодні в Україні та світі під час виборчих кампаній. Якщо говорити про сам термін «популізм», то він передбачає перш за все загравання політиків зі своїм народом, своїми виборцями з метою отримання всенародної популярності й, у кінцевому результаті, завоювання та утримання влади.

Серед західних вчених, які займалися дослідженням феномену популізму можна назвати I. Берліна, Е. Геллнера А. Валіцкі, Г. Іонеску та інших. 3 українських науковців варто назвати таких: В. Ачкасов, В. Бебик, А. Бобрук, Д. Богуш, С. Денисюк, Л. Кочубей, І. Новоженова, С. Погорельска, Х. Функе, Л. Ренсманн, Ю. Шайгородський, О. Ярош тощо.

Варто відзначити, що у роботах українських авторів аналізувалися та пояснювалися причини виникнення і поширення популізму в різних суспільствах, міра його впливовості на прийняття рішень громадянами та інше.

Історична наука чітко демонструє, що політичні діячі у різні часи намагались збільшити кількість своїх прихильників за допомогою різних технологій, в тому числі, популізму. Наприклад, у 1891 р. у США було засновано Народну партію, яка активно використовувала популізм, як вид боротьби за права громадян. Опісля він розвивався у різних варіаціях та видах. Відтак, відомий приклад «гандизму» в Індії, чи «перонізму» в Аргентині (Ярош О., 2002).

Також, можна побачити, що й у сьогоднішніх реаліях популізм часто використовується різними політиками, він по суті виступає атрибутом політичної риторики, ангажування i реклами. Так, в Італії можна назвати Беппе Грілло, популістська партія якого нещодавно посіла третє місце на виборах, а очолює ії комік в минулому.

Аналізуючи місцеву виборчу кампанію 2015 року слід згадати про українську вчену О. Ремовську, яка стверджувала, що у нашій країні багато партій, які використовують популістські ідеології. До таких можна віднести «Радикальну партію», нову партію «Укроп» 
та «Свободу». Відповідно, їхній відсоток у сумі буде більшим, ніж десять. Це є достатньо великою цифрою, якщо вірити міркам Свропейського союзу (Ремовська О., 2015).

Ще одна українська дослідниця І. Біла говорить, що перед президентськими виборами у березні 2019 році в Україні все частіше загострюється головна ідеологія країни - це популізм. Так, неодноразово акцентувалося на тому, що популізм стає своєрідною «міною уповільненої дії», навкруги розставлені «пастки популізму», а політики декларують не власні погляди і навіть не власні плани, а те, що найкраще сприймається виборцем, що йому подобається чути. Це навіть стало поштовхом до того, що у лютому 2019 р. на сайті електронних петицій зареєстрували звернення про запровадження кримінальної відповідальності за невиконання політичних обіцянок (Біла I., 2019).

Окрім самих політиків, політичних лідерів і партій, слід сказати про інший бік популізму, а саме про сприйняття популізму суспільством. Адже саме воно формує запит та очікування на популізм. Це відбувається насамперед тому, що люди незадоволені поточним станом речей, формою правління в державі, вони «політично голодні», їм потрібне щось нове. Тому суспільство починає хотіти чогось нового, нетипового і неординарного.

На хвилі політичної новизни завжди знайдеться той, чиї популістські висловлювання припадуть до душі людям. Відповідно, цю людину буде обрано лідером-популістом. І це буде якраз великою помилкою. Адже тільки суспільство, яке не вміє критично мислити, аналізувати, порівнювати ситуацію може зробити такий фатальний вибір.

Тут слід навести як приклад твердження ще одного українського науковця О. Савицького, який теж має своє бачення популізму: «Багато українців зараз шукають легких відповідей на економічні виклики і готові підтримати тих, хто робить хоча б видимість розв'язання їхніх проблем. Ми вже бачимо приклади нестримного популізму на довиборах у місцеві органи влади у 2015 році на окрузі в Чернігові, де кандидати роздають виборцям продуктові набори та вишиковують великі черги за безкоштовними обідами» (Савицький О., 2015).

Це добре ілюструє те, що люди дійшли вже до такої межі, що готові буквально за їжу «продавати» свої голоси.

Варто згадати також відомого французького державного діяча та суспільствознавця Алексіса де Токвіля, який мав свою точку зору з приводу популізму. Він стверджував, що саме демократія $є$ недосконалою формою популізму, але кращої форми правління не існує (Де Токвіль А., 1999, с.341).

Суть в тому, що популізм певною мірою може випливати 3 демократії, адже єдина відмінність між демократією та популізмом, це те, що під час демократії обіцяне виконується і контролюється суспільством, а під час популізму - ні, є суто гарні слова і жодних дій, люди засліплені цим та продовжують вірити гучним гаслам, словам.

Доцільно зазначити також про пошук та визначення своєрідного критерію ідентифікації самого популізму.

Відтак, український вчений-соціолог Т. Радь говорить про можливість диференціювати популістський і непопулістський «продукти» під час виборчих кампаній. Розглядається ситуація, за якої популізм постійно оцінюється із точки зору етики, і тому морально- етичний підхід не здатний відмежовувати його від інших суспільно-політичних явищ. У цьому випадку популізм варто трактувати як форму реалізації масової політики, що $є$ набагато ширшим, ніж ідея просвітництва народу. А демагогія $є$ просто негативною формою прояву цього процесу в інтересах окремого суб'єкта. Тому можна визначити популізм як відповідний суспільнополітичний рух, політичну «ідеологію», стратегію влади, тип поведінки та дій тощо. Його можна виокремити 3-поміж інших суспільно-політичних явищ, але не маємо підстав однозначно кваліфікувати будь-який зразок комунікації як популістський» (Радь Т., 2012, с.288).

Слід зазначити, що об'єктивним параметром визначення популізму є результат реалізації політичних обіцянок, програм, гасел тощо. Так, західні науковці М. Дейвіс та М. Феррантіно розвинули теорію політичної риторики, за якою кандидати на виборах свідомо брехатимуть, оскільки вони неспроможні передати цінність власної репутації як чесних політиків (Дейвіс М., Феррантіно М., 1996, с. 5). 
Таким чином, підсумовуючи, можна точно казати, що, по-перше, популізм є ідейноспекулятивною орієнтацією політиків на політичні очікування і бажання широких суспільних мас, вони використовують незадоволення людей своїм життям.

По-друге, як вже зазначалося раніше, популізм використовується політиками в якості ефективної технології для здобуття та утримання влади.

\section{References}

Yarosh, O. (2002) Political Populism: The Theory and Practice of Election Flirting, / O. Yarosh., - Retrieved from: http://www.ya.org.ua/old/brochure /2002/005/ 003.htm.

Removskaya, O. (10/17/2015) Populism thrives because part of society seeks quick and easy decisions, / O. Removskaya // Radio Svoboda - Retrieved from: content / article / 27224118.html.

Bila, I. (2019, April) 2019 Election: Populism Becomes a Slow Motion (Press Review). Retrieved from: https://www.radiosvoboda.Org/a/29646070.htm

Savitsky O. (07/22/2015) Yulia Tymoshenko again in the leaders: irrevocable populism? / O. Savitsky // Made for minds. - Retrieved from: http://www.dw.com/ uk - 18599061.

De Tocqueville, A. (1999) On Democracy in America / A. de Tocqueville // The Electorate. - Kyiv: 577 c. Retrieved from :: http://litopys.org.ua/tocq/toc.htm.

Радь, Т. (2012, Мау 5) Популізм як продукт політичної комунікації / Т. Радь // Вісник Львівського університету. Серія філософські науки. - №15. - С.287-296

Davis, M. A, \& Ferrantino, M.S. (1996, September 9) Towards a Positive Theory of Political Rhetorics: Why Do Politicians Lie? // «Public Choice», - №88 (1-2). - P.1-13.

\section{Список використаної літератури}

Ярош, О. (2002) Політичний популізм: теорія і практика передвиборного «флірту», / О. Ярош., - Retrieved from: http://www.ya.org.ua/old/brochure /2002/005/ 003.htm.

Ремовська, О. (17.10.2015) Популізм процвітає, бо частина суспільства прагне швидких i простих рішень, / О. Ремовська // Радіо Свобода - Retrieved from: content/ article/27224118.html.

Біла, I. (2019, April) Вибори-2019: популізм стає міною уповільненої дії (огляд преси). Retrieved from: https://www.radiosvoboda.Org/a/29646070.htm

Савицький О. (22.07.2015) Юлія Тимошенко знову в лідерах: безвідмовний популізм? / О. Савицький // Made for minds. - Retrieved from: http://www.dw.com/ uk-18599061.

Де Токвіль, А. (1999) Про демократію в Америці / А. де Токвіль // "Ізборник". - К: 577 с. Retrieved from:: http://litopys.org.ua/tocq/toc.htm.

Радь, Т. (2012, Мау 5) Популізм як продукт політичної комунікації / Т. Радь // Вісник Львівського університету. Серія філософські науки. - №15. - С.287-296

Davis, M. A.,\& Ferrantino, M.S. (1996, September 9) Towards a Positive Theory of Political Rhetorics: Why Do Politicians Lie? // «Public Choice», - №88 (1-2). - P.1-13.

\section{Contact information:}

Yaroslav Farion yarkof@gmail.com 